Democracy and Economic Liberalism: The Foundations

of Hope in Africa

Michael A. Kelley, University of Central Arkansas

The failure of many African regimes since independence to materially advance the quality of life and freedoms of their citizens has created a paradigm shift in development policy. Emphasizing the real capacity for autonomous choice among national and local elites, there is an ever-increasing recognition of the linkage between the use of free market mechanisms to promote national well-being and the provision of a democratic government. Data suggest that democratic and/or market driven states have fared better in Africa than those which embraced more controlled political and economic regimes.

For many academics Africa truly became the "dark" continent during recent decades, when the gloom and despair engendered by economic collapse, social disarray, and political instability led some to call into question even the survival of some of the peoples of the area, as well as certain regimes and civil societies (Turnbull 1972; Whitaker 1988). The scholarly disillusionment with the region was predicated on its declining economic fortunes (defined by falling market prices for African products), the existence of bloated, wasteful, and overly centralized bureaucracies and parastatal organizations promulgating economically dysfunctional rules, the general inability of African states to generate adequate levels of domestic investment (Vengroff 1990), and the prevalence of authoritarian governments that deny their peoples the fundamental liberties requisite to real modernization and development (Ake 1990).

To some scholars, particularly of the dependency school, the failure of the Third World to create the wealth necessary for national autonomy and development was occasioned by the nature of the capitalist world-economy which effectively impoverishes African states (Wallerstein 1976). To structuralists like Wallerstein (1971), the reality of the international economic order limits options for any government or, as Lofchie puts it, "in all these fundamental political matters Africans do not possess realistic political choices" $(1971,18)$. The rather depressing conclusion of this approach is that Africa will remain the dark continent, failing some kind of millennial transmogrification of the international power structure or a willingness by Africans to abjure Western styles of development and standards of living while seeking self-reliant domestic economies.

On the other hand, the scholarly approach that emphasizes the centrality of public choice and of indigenous decision-making to relative levels of national wealth, status, and development (Nau 1990; Ilchman and Uphoff 1971; Chazan, 
et al. 1988; Hodder-Williams 1984), while recognizing the region's place in the world economy and its cultural and historical inheritances, gives one some hope that Africa can utilize the human genius and physical resources it possesses to achieve real improvements in the quality of the lives of its various peoples. To the extent that current problems are the result of Africans making "a dreadful tangle of their economic affairs since Independence" (Whitaker 1988, 2), the benighted nature of the continent is the result of failed national purpose and policy choices rather than the ineluctable result of core-periphery relations. And if, as HodderWilliams believes, the "leaders of Africa are not political eunuchs" $(1984, \mathrm{xx})$ and third world countries are by-and-large the masters of their own history (Smiley 1982; Zacher and Milne 1974), then it is possible to gainsay the dependency doomsayers and discover in the appropriate political choices an effective way to deal with the vast array of problems facing the continent. In fact, the rejection of the rather paternalistic view that only the core nations hold the key to Africa's future development is reflected in the sentiment expressed by the African group at the United Nations when it said "Africa has taken the main responsibility for its own development" (The Economist 4 March 1989, 14), and by the impressive list of reforms initiated by African governments since 1982 when they began the process of "seeing things differently," as noted by Whitaker (1988, 203-206).

If one accepts that human volition plays a crucial role in national development, then the central question for government leaders revolves around which set of policies is most instrumental in promoting modernization in Africa. It is certainly apparent that the dominant one-party, highly centralized, and authoritarian state paradigm which characterized much of post-independence Africa has been an unmitigated disaster, as noted by Wunsch and Olowu (1990), Fatton (1990), Chege (1988), and Sklar (1983). Fortunately, there exists sufficient international evidence to suggest that while "autocracy and economic collapse were causally related" (The Economist 22 December 1990, 75), democracy and economic well-being also are interrelated in Africa (Nyong'o 1990). If President Museveni of Uganda is correct and "development is linked to democracy" (Mbembe 1990), Africa must choose the path most conducive to the emergence of democratic polities. It is argued here that Africa should borrow Nkrumah's (1965) vision of a continental identity and couple it with economic liberalism's celebration of the liberating and productive character of free markets to guide it into the 21 st century. Though very strange bedfellows in terms of origins, the development of a centralizing and truly African identity may in large part be conditioned by the willingness of African states to devolve control over their productive forces to individuals and free markets.

\section{Africa's Problems}

Bohannan and Curtin (1988, 387-390) summarize the well-known failings of African economic policies since independence. Only nine continental black 
African states enjoyed annual GNP per capita (GNP/PC) growth of 2.0 percent or higher between 1960-1981, while eight black continental states actually had negative growth rates during the same period. They further conclude that while general economic policy was a disaster, food production was, if possible, even worse. According to Chege $(1988,194)$, the "average annual growth rate of agricultural production per capita has been negative (-1.1 percent) between 1970 and 1982 and a similar situation is observed in food production where the figure is -1 percent." Systematic exploitation of food producers to pay for development projects and to maintain urban standards of living did much both to impoverish rural areas and contribute to the famine that gripped Africa during recent years. In fact, between 1980 and 1988 the average African found himself getting poorer, with average GNP per capita shrinking at a rate of .05 percent a year (The Economist 23 September 1989,40), and personal real income 10 percent lower in 1989 than in 1970 (The Economist 4 March 1989, 13). Table 1 below is further evidence of the general failure of economic policy in Africa that has led to a situation where, for the poorest ten African states, a real average income growth rate of 1 percent a year for 50 years will produce an income equal to that currently enjoyed by the average Indian citizen.

Table 1. Africa's Relative Decline

\begin{tabular}{|c|c|c|c|c|c|c|c|c|c|c|}
\hline & \multicolumn{4}{|c|}{ GNP* } & \multicolumn{2}{|c|}{ GNP/PC** } & \multicolumn{2}{|c|}{$\begin{array}{l}\% \text { Share of } \\
\text { Global GNP }\end{array}$} & \multicolumn{2}{|c|}{$\begin{array}{l}\text { GNP/PC as } \\
\% \text { of Global } \\
\text { GNP/PC }\end{array}$} \\
\hline & & & Young & & & Young & & Young & & Young \\
\hline & Globe & Africa & Dragons $^{\mathbf{a}}$ & Globe & Africa & Dragons ${ }^{2}$ & Africa & Dragons & Afric & Dragons \\
\hline 1978 & 9,489 & 156 & 89 & 3700 & 620 & 3522 & $(1.74)$ & $(2.41)$ & 18 & (95) \\
\hline 1980 & 11,930 & 227 & 115 & 3785 & 718 & 3865 & $(1.90)$ & (3.03) & 9 & $(102)$ \\
\hline 1982 & 14,130 & 263 & 15 & 3711 & 673 & 4302 & $(1.86)$ & $(4.06)$ & 18 & (116) \\
\hline 1984 & 16,200 & 283 & 195 & 3814 & 634 & 5083 & (1.75) & $(5.11)$ & 7 & (133) \\
\hline 1986 & 18,100 & 310 & 240 & 3898 & 619 & 5426 & $(1.71)$ & $(6.15)$ & 16 & (139) \\
\hline 1988 & 20,640 & 339 & 312 & 4028 & 600 & 6428 & (1.64) & $(7.77)$ & 15 & (160) \\
\hline
\end{tabular}

*In billions of current dollars.

** In current dollars.

singapore, Taiwan, South Korea.

Source: Economic data are from U.S. Arms Control and Disarmament Agency (1989).

The small decrease in the continent's share of global GNP disguises the more unpleasant reality of both the real and relative decline in Africa's GNP/PC vis- $a$ $v i s$ the rest of the world. It is quite likely that in many cases whatever increases African states registered in overall GNP levels were more a reflection of population growth than of any economic modernization. What makes the African data even more unsightly is the success of three of Asia's four "young dragons," also noted 
in Table 1. Though having little arable land, few natural resources, and population densities higher than any country save Hong Kong and Bangladesh, as a group these nations more than tripled their share of global GNP between 1978 and 1988, while evolving toward greater democracy at home. Though using different methods, the governments predicated their success on eschewing autarky and embracing an export oriented economy, as well as using the free market essentially to direct price levels and economic decisions (The Economist 14 July 1990, 19). Choices made by the "young dragons" and other developing states facilitated growth while, in most cases, the choices of African states resulted in economic failure.

Perhaps the most striking example of the importance of proper economic choices is the contrast between Ghana and South Korea. In 1957, Ghana was the richest country in black Africa, and had the best educated population. Its primary, extractive enterprises (cocoa, gold, diamonds, bauxite, manganese, and mahogany) were quite lucrative, and its per capita income was $\$ 490$ compared to South Korea's \$491 (in 1980 dollars). However, by the early 1980s South Korea's per capita income was five times that of Ghana, its life expectancy had risen from 58 years in 1965 to 70 years in 1988, its workforce had dropped (in forty years) from 77 percent agriculturally-employed to 25 percent so employed, income inequality sharply declined, and 37 percent of Koreans received some higher education. In contrast, Ghana's per capita income had actually fallen -- by nearly 20 percent - to $\$ 400$. Between 1970 and 1982, real income per head fell 30 percent, real wages fell 80 percent, investment slumped from 20 percent of the GDP in the 1950s to 4 percent by 1982, and exports fell from more than 30 percent to 3 percent of GDP (The Economist 23 September 1989 and 14 July 1990).

Unfortunately, in addition to poor governance (as in Ghana), there are other situational variables that also militate against efforts to apply East Asia's economic (and political) development lessons to Africa. Ethnic agitation, chauvinism, political instability, and corruption (Alozie 1991, 5), along with class conflicts (Fatton 1990, 469) and cultural impediments (Palmer 1989, 332-335), will continue to remain obstacles to development no matter how potentially salubrious an approach to the region's problems. As Morrison (1989, 82-91) demonstrates, between 1970 and 1982 Africa experienced an average of 5.16 coups/coup attempts a year, 5.39 events per year characterized as irredentist, civil warfare, or rebellion, and 18 events of mass revolution/revolt. Obviously, the strains and stresses on fragile African political institutions occasioned by "central-local tensions, factionalism and intensive competition, inexperience in political office and a pervasive tradition of opposition to central government" (Morrison 1989,83) mean that many governments have failed their first obligation to provide the political stability necessary for effective economic choices.

Exacerbating government difficulties is the on-going problem of ethnicity and subnational identification. Recognized as a possible obstacle in early works on political development (Von der Mehden 1964; Pye 1966; Weiner 1971; Geertz 
1971; Gamer 1976), the destructive aspect of ethnic divisions in African states has dashed Enloe's hope that, for purposes of modernization, "ethnic identity can be a building block" $(1973,3)$. Given the more than 1,000 languages spoken in Africa, Peil's $(1977,128)$ characterization of Nigerian politics as having a "potential for factionalism [that] seems to be infinite" may be generalizable to the entire continent (Morrison 1989, 46). Although not all African states are cursed with divisive ethnic fragmentation (e.g., Tanzania, Somalia, and Botswana), Alozie's portrait of the continent's richest black African state, torn by a devastating ethnic war in the late $1960 \mathrm{~s}$, illuminates the obstacles that embedded ethnicity presents to central government efforts to foster economic growth:

Since Nigeria's domestic politics is largely entrenched in [the] regionaltribal nexus[,] bureaucratic power tends also to mirror tribal (political) power. Accordingly, tribal affiliation (rather than portfolios held) becomes an important determinant of power legitimation and the pattern of loyalties within public organizations. Thus, like the pattern of recruitment itself, many public institutions have degenerated into instruments for advancing intratribal social welfare and inter-tribal imperialism. Incidentally, this anomaly continues to divert attention away from the need to control individuals' excesses and thus provides the shield under which excessive misappropriation of public resources proceeds virtually unabated (Alozie 1991, 6).

Compounding the problems of ethnicity, poor economic performance, and the prevalence of one party/military regimes is the problem of corruption, which has been far from petty, given the limited fiscal and identitive resources available to African governments. Although corruption is endemic to all governments, its pervasiveness and scope in Africa constitute "a great evil" (Tubman 1986, 116). Africans' consciousness of corruption is manifest in the wry use of the term Wabenzi, coined in the early 1960s in Tanzania to designate as a new "tribe" those with access to a Mercedes-Benz (Hodder-Williams 1984, 108). Government is burdened not only by bribery, favoritism, and misappropriation of funds, but also by bloat and inefficiency due to the hiring of inordinate numbers of often incompetent tribal associates, as well as the accelerating proliferation of innovation-strangling rules and regulations. After all, the greater the number of rules, the greater the opportunity to make a "profit" from a government post (Hyden 1983, 101-102). All in all, Harrison's assessment of the baleful effects of corruption is accurate:

Corruption is the cancer at the heart of most Third World states. It eats away at the foundations of trust between people and their rulers. It exemplifies the two key weaknesses of the developing state: the unholy marriage of political and economic power, whereby money buys influence, and power attracts money; and the 'softness' of the state, to use Gunnar Myrdal's term -- its inability to apply and enforce its own laws and regulations, so that reform, even if it is legislated, rarely gets put into effect $(1981,367)$. 
Certainly, the frustration of African political and economic performance rests on more than political instability, ethnicity, and corruption, but these are major factors that are typical of the problems that confront any attempt at modernization. Inasmuch as some African states have been able to mitigate, though not eliminate, the effects of these phenomena upon economic development, appropriate national decisions can lead to beneficent consequences. It is contended here that democracy and reliance on market forces for economic decisions are positively associated, and that these choices correlate with economic success, though in less than a causal manner.

\section{Africa's "Successes"}

Given the rather dismal performance of African states in general, especially when compared to East Asia's "young dragons," success is a relative term. Yet it is the relative performance of certain regimes, and not others, that is the basis for the growing conventional wisdom that "tyranny is negatively associated with development" (Ake 1990, 3). Bates $(1990,30)$ notes that in an economic era in which organizations that emphasize the real potential of human capital are more successful than centrally planned systems, it is likely that governments concerned with economic growth "therefore may seek to surrender control over decisions to those who control the key resource." Examination of relative GNP and GNP/PC performance in the light of Chazan, et al.'s (1988, 133-145) classification of African regime types should provide a test of the correctness of this view.

Table 2 provides some evidence of the importance of regime type to economic development. Certainly, the pluralist governments weathered the vicissitudes of the decade better than the party-centralizing states. It should be noted that those party mobilizing and administrative-hegemonical regimes that were successful in elevating GNP/PC over the decade are primarily more market driven and open economies (Cameroon, Zimbabwe, and Kenya). Aggregate data often can obscure the real picture, especially when data is as poor and suspect as in Africa. It is useful, therefore, to examine the experience of Senegal, the one African state which made a peaceful or non-military transition from a single party political system to a democracy (Wiseman 1990,28). As a single-party state prior to 1976 , Senegal's economic performance was consistently below continental norms, with its GNP/PC below the African average every year and its rates of increase in GNP during 1970-1977 (15 percent) and GNP/PC during 1971-1977 (6.7 percent) behind the regional increases of 113 percent and 12.54 percent, respectively, during those same periods. On the other hand, since embracing democracy Senegal has enjoyed an economic renaissance. Between 1978-1988, Senegal's GNP/PC was higher than the regional average six out of eleven years, and its GNP and GNP/PC grow th outstripped regional performance by 134 percent to 117 percent, and 3.51 percent to -3.23 percent, respectively. Though only suggestive, Senegal's experience points to both the possible positive relationship 


\section{Democracy and Economic Liberalism}

Table 2. Regime Types and Economic Performance, 1978-88

\begin{tabular}{|c|c|c|c|c|c|}
\hline GNP* & GNP* & $\%$ Change & GNP/PC & GNP/PC & $\%$ Change \\
\hline 1978 & 1988 & $\begin{array}{l}\text { In GNP } \\
1978-1988\end{array}$ & 1978 & 1988 & $\begin{array}{c}\text { In GNP/PC } \\
1978-1988\end{array}$ \\
\hline
\end{tabular}

\section{Pluralist Regimes}

$\begin{array}{lrrcrrr}\text { Botswana } & \$ 294 & \$ 1204 & 310 \% & \$ 599 & \$ 1011 & 69 \% \\ \text { Gambia } & 81 & 199 & 146 & 221 & 256 & 16 \\ \text { Mauritius } & 436 & 929 & 118 & 502 & 484 & -04 \\ \text { Senegal } & 2018 & 3561 & 77 & 626 & 649 & 04 \\ \text { Average } & 707 & 1472 & 163 & 487 & 600 & 21\end{array}$

Ratio of Average GNP/PC to GNP/PC for all Africa

$79.6 \% \quad 100 \%$

Administrative - Hegemonical Regimes

$\begin{array}{lrrrrrr}\text { Cameroon } & 3776 & 12300 & 226 & 781 & 1167 & 49 \\ \text { Kenya } & 3148 & 8254 & 162 & 344 & 354 & 03 \\ \text { Ivory Coast } & 4957 & 8728 & 76 & 1093 & 780 & -29 \\ \text { Malawi } & 691 & 1388 & 101 & 205 & 181 & -12 \\ \text { Nigeria } & 16900 & 28690 & 70 & 336 & 256 & -23 \\ \text { Togo } & 704 & 1300 & 85 & 482 & 390 & -19 \\ \text { Zaire } & 2170 & 2653 & 68 & 686 & 484 & -29 \\ \text { Average } & 4438 & 8782 & 110 & 517 & 474 & -10\end{array}$

Ratio of Average GNP/PC to GNP/PC for all Africa

$83.4 \% \quad 79 \%$

Party Mobilizing Regimes

$\begin{array}{lrrrrrr}\text { Ghana } & 2697 & 5006 & 86 & 428 & 349 & -19 \\ \text { Guinea } & 1068 & 2261 & 112 & 340 & 327 & -04 \\ \text { Mali } & 849 & 1912 & 125 & 214 & 221 & 03 \\ \text { Tanzania } & 1429 & 2873 & 101 & 135 & 118 & -13 \\ \text { Zimbabwe } & 2424 & 6112 & 152 & 593 & 628 & 06 \\ \text { Average } & 1693 & 3633 & 115 & 342 & 329 & -05\end{array}$

Ratio of Average GNP/PC to GNP/PC for all Africa

$55.1 \%$

$54.8 \%$

\section{Party Centralizing Regimes}

$\begin{array}{lrrrrrr}\text { Angola } & 5088 & 11240 & 121 & 1354 & 1364 & 01 \\ \text { Benin } & 744 & 1634 & 111 & 402 & 363 & -10 \\ \text { Ethiopia } & 2537 & 5511 & 117 & 113 & 114 & 00 \\ \text { Guinea-Bissau } & 70 & 142 & 103 & 156 & 149 & -05 \\ \text { Mozambique }^{2} & 997 & 1010 & 01 & 117 & 68 & -42 \\ \text { Average } & 1893 & 3907 & 91 & 434 & 423 & -10\end{array}$

Ratio of Average GNP/PC TO GNP/PC for all Africa

$68.2 \%$

$70.5 \%$

*In millions of current dollars.

'Data from 1980 instead of 1978 are used for Mozambique.

Source: Economic data is from U.S. Arms Control and Disarmament Agency (1989). 
of democracy and economic development and the likelihood that data viewed within a narrower research focus may illuminate trends obscured by aggregate data.

Table 3, based on a coupling of Morrison's $(1989,137-229)$ "Country Profiles" with Chazan, et al.'s (1988) regime typology, illustrates that political stability, a requisite part of developmental infrastructure, also seems to be more characteristic of democratic and/or economically successful states than the other regime types. The democratic states, as a group, have had more economic success, in part because they avoided the dislocations and costs associated with political unrest and regime failure. While the issue of which direction the causal arrow flows in is beyond the scope of this paper, it bears repeating that Zimbabwe, Kenya, and Cameroon -- non-democratic but economically successful regimes, according to the data in Table 2 -- are not only politically stable but also have more open, market driven economies. Indeed, some now characterize Zimbabwe as a democracy (Morrison 1988; Wiseman 1990) while Cameroon and Kenya are scheduled to hold competitive elections shortly (The Economist 28 February 1992 , 18).

To the extent that we can rely on the above information, it is possible to draw some very tentative conclusions concerning relative regime performance. It is apparent that at the polar extremes, i.e., pluralist and party-centralizing types, the former significantly outperform the latter in both levels of economic development and overall political stability. The data also indicate that economic success in party-mobilizing (if one accepts the placement of Zimbabwe in this category) and economically successful administrative-hegemonical states, such as Kenya and Cameroon, is conditioned by the existence of relative political stability and open, market-driven economies. It appears that democracy, political stability, open/ market economies, and economic success are associated with each other in Africa. On the other hand, regimes that are unstable, undemocratic, and have governmentdriven economies have been singularly unable to promote economic development. Certainly, though the data may be somewhat suspect, there is sufficient evidence to lead African leaders to believe, as some already do, that the best route to development is that of political democracy and market-sensitive economies.

\section{Economic Liberalism: Democracy and Development}

To the extent that Africa has been a continent of ideology, it is crucial not only to make the intellectual connection between market economies and democracy but also to realize, as Nzouankeu (1991) points out, that the African democratic revolution is the product of the failure of the ideas of consensual democracy, the "democratic" one-party state, and an "African" conception of human rights. It is obvious from the above data and from the Taiwanese and South Korean experiences that it is quite possible to have some real measure of economic success without being a full-fledged democracy. As The Economist (20 June 1987, 


\section{Democracy and Economic Liberalism}

Table 3. Economic System, Regime-Type, and Political Instability

\begin{tabular}{lcc}
\hline Economic & Incidence of \\
System $^{2}$ & State & Governmental Instability
\end{tabular}

\section{Pluralist Regimes}

$\begin{array}{lll}\text { Market } & \text { Mauritius } & \text { Temporary state of emergency - 1971. } \\ \text { Market } & \text { Senegal } & \text { Coup attempt - } 1962 \text { (Democracy since 1967). } \\ \text { Participation } & \text { Botswana } & \text { Stable. } \\ \text { Participation } & \text { Gambia } & \text { Coup attempt }-1981 .\end{array}$

Administrative-Hegemonical Regimes

\begin{tabular}{|c|c|c|}
\hline Market & Kenya & Coup attempt -1982. \\
\hline Market & Nigeria & $\begin{array}{l}\text { Coups }-1966(2), 1975,1983,{ }^{b} 1985^{b} \\
\text { coup attempt }-1967 .\end{array}$ \\
\hline Participation & Cameroon & Stable. \\
\hline Participation & Ivory Coast & Stable. \\
\hline Participation & Malawi & Stable. \\
\hline Participation & Zaire & $\begin{array}{l}\text { Coups - 1960, 1965; coup attempt - 1963; } \\
\text { insurrection - 1977-1978. }\end{array}$ \\
\hline fixed & Zambia & Stable. \\
\hline ate Control & Togo & Coups - 1963, 1967; coup attempt - 1966. \\
\hline
\end{tabular}

Party-Mobilizing Regimes

\begin{tabular}{|c|c|c|}
\hline Market & Zimbabwe & Stable. \\
\hline Mixed & Ghana & $\begin{array}{l}\text { Coups - 1966, 1972, 1978, 1979, 1981; } \\
\text { coup attempt - } 1967 .\end{array}$ \\
\hline State Control & Guinea & Coup attempts - 1968, 1970. \\
\hline State Control & Mali & Coup - 1968. \\
\hline State Control & Tanzania & Coup attempt - 1972. \\
\hline
\end{tabular}

Party-Centralizing Regimes

\begin{tabular}{lll}
$\begin{array}{l}\text { Planned } \\
\text { Planned }\end{array}$ & $\begin{array}{l}\text { Angola } \\
\text { Benin }\end{array}$ & $\begin{array}{l}\text { Coup - 1977; civil war 1975-present. } \\
\text { Coups - 1963, 1965, 1967, 1969, 1972; } \\
\text { coup attempts - 1972, 1975, 1977. }\end{array}$ \\
Planned & Ethiopia & $\begin{array}{l}\text { Coups - 1974, 1977; coup attempt - 1960; civil } \\
\text { wars. }\end{array}$ \\
Planned & Guinea-Bissau & $\begin{array}{l}\text { Coup - 1980. } \\
\text { Planned }\end{array}$ \\
\hline
\end{tabular}

Information derived from Vanhanen (1990, 252-274). For an explanation of these economic system types, see note 2 .

bSupplementary Information from Wiseman (1990). 
18) notes, "Kenya is not the first country where rising prosperity has grown from liberal economics, laced with corruption and sustained by autocracy." Yet it is just this type of example that underlines the importance of demonstrating the link between democracy and economic liberalism, which arguably has the desirable end of empowering individuals in the economic and political spheres of their lives while also creating hope for future human and societal development. If Bates' $(1991,27)$ assertion is correct, national prosperity in the future may well be determined by the willingness of government to "surrender control over decisions to those who control the key resource: the people themselves."

Hayek (1944, 1948), the Friedmans (1962,1980), and Novak (1982) would not be surprised by the juxtaposition of the denial of political democracy with the failure of centrally planned economies in Africa. As Usher $(1981,2)$ points out, for Hayek and the others, "economic policy is not autonomous. . . economic policy can affect the political realm" (an idea very familiar to students of African political thought). Such economic liberals regard that "political democracy is compatible in practice only with a market economy" (Novak 1982, 14); and that "the combination of economic and political freedom produced a golden age" in the West (Friedmans 1980, 3). Future growth and progress in both areas is contingent upon the continued celebration of the individual (Hayek 1948). De Tocqueville, quoted by Hayek $(1944,25)$, reflected this view of the relationship between political and economic freedom:

Democracy extends the sphere of individual freedom, socialism restricts it. Democracy attaches all possible value to each man; socialism makes each man a mere agent, a mere number. Democracy and socialism have nothing in common but one word: equality. But notice the difference: while democracy seeks equality in liberty, socialism seeks equality in restraint and servitude.

Essentially, economic liberals despair of the planners' claimed capacity to rationally decipher production, technological, and consumer trends sufficiently to render the economy adaptable enough for efficient growth. The vagaries of human choice, reflecting individual perceptions of what is important, are far more efficient drivers of the economy than central planners' directives, for there is no single rational decision or objective economic truth, other than that determined by the sum of the individual choices made by citizens. To subordinate individual to government choice disenfranchises the person in all realms of life and also will lead to economic inefficiency, as noted by Hyden $(1983,200)$, who estimates that "Tanzania's losses through self-inflicted agricultural decline, mainly as the result of regulating the market out of operation, are approximately 250 percent greater than the losses incurred because of higher oil costs, and are roughly equal to foreign aid [it] received between 1973 and 1980." As The Economist (14 July 1990, 11) explains: 
Self-interest and competition silently process staggering quantities of information and direct the flow of goods, services, capital and labor -- just as in [Adam] Smith's much simpler world.... With great effort and ingenuity, and the systematic denial of personal liberty, governments can supplant self interest and competition, and replace the invisible hand of market forces with collective endeavour and a visible input-output table. The result is a five-year waiting list for Trabants.

In retrospect, Africa's flirtation with socialism and state-controlled enterprises seems to be more quixotic than rational, arising from its pardonable distaste for most things western (colonial). The economic lessons that could have been learned from Eastern Europe were ignored, as were the consequences of centralized planning for the condition of liberty. Hayek worried about what Lenin called "Who, Whom: who plans whom, who directs, chooses, allocates what to whom?" Such a system "spelled the end not only of capitalism but of personal liberty as well" (Heilbroner 1961,263). Echoing Hayek, James Q. Wilson $(1990,570)$ notes "there is a fundamental conflict between an activist democracy and a juridical democracy .... one can have administrators with clearly defined powers or administrators with great powers, but one cannot have both."

Africa deserves more, however, than a reminder that many states made an incorrect choice when they opted decades ago for administrators with great rather than limited power, for which they are still suffering. Rather, the case needs to be made for greater democracy and market-sensitive economies as solutions for the continent's problems.

What is problematic today is that even those statist resources for which African regimes opted are still too scarce to enable them to attain even Eastern Europe's relatively poor levels of economic performance. Where are the legions of public-spirited, well-trained planners necessary to manage the almost 20 percent share (double the average for both developed and other developing countries) of African GDP that state-owned enterprises accounted for in 1986 (Whitaker 1988, 53)? Unfortunately, the Zambian experience of having fewer than 100 college graduates and fewer than 1,000 secondary-school graduates upon independence (Hodder-Williams 1984, 86) was not uncommon. The consequence of centralized planning was to place on government's shoulders responsibility for scarcity of resources, lack of legitimacy, inadequate power, strong patterns of social differentiation, and lack of policy flexibility (Chazan, et al. 1988, 19-21, 62). Government stability under such circumstances has been less than satisfactory. In Africa's soft states, in which "weaknesses in the public realm exist and clan politics still prevail" (Hyden 1983, 60-63), capitalism should be more effective than planned economies at securing both development and democracy. Capitalism will transform the peasant mode of production, thereby attracting peasants into the system, changing bonds of affection, and birthing a social class able to deal effectively with international capital and markets (Hyden 1983, 2529). Usher $(1981,141)$ identifies the crucial problem to be political assignment of income, 
which ineluctably corrupts democracy, economics, and public support for government:

It is at least arguable that the resurgence of regionalism and ethnic solidarity and the increasing tension in many countries between worker and management, rich and poor. ... are symptoms of the increase in the share of income that the legislature has to assign. In Canada, the deterioration of equity and the increasing dependence of each man's income upon negotiation with government ... may have contributed to the present situation, where conflict among regions is greater than before, and where English and French may be finding themselves unable to live within the same country.

There are other advantages to reducing the power of government to assign wealth, status, and privilege by diffusing responsibility for success to more impersonal and less (politically) contentious and disruptive market forces. One is reducing the scope of corruption. The marketplace is unfriendly to most forms of inefficiencies, of which corruption is a good example. Moving away from various African forms of kula, a Swahili word that means "to eat" (here, the ability to use public resources for personal and clan benefit), will increase economic efficiency, although new mechanisms to create political loyalties will have to be found since patronage is often a significant means of creating regime support (Hyden 1983, 37). Also, bloated bureaucracy can be trimmed, resulting in both lessened opportunities for corruption and substantial economic savings to the state. Although many African states such as Tanzania -- which laid off 25,000 government workers in 1985 (Whitaker 1988. 205) -- have begun the process of economic reform, the opportunity for additional savings of scarce resources remains immense. Chazan, et al. $(1988,52)$ cite a study that indicates that while Tanzania's average annual GDP and total wage employment expanded between 1966 and 1980 at rates of 3.88 percent and 2.84 percent, respectively, the size of the civil service grew during the same period at an average annual rate of 13.3 percent, from 65,708 state posts to 295,352 .

One can only hope that, as Africans are weaned away from political action to secure wealth for themselves and their clans, the economic motivations and values requisite for weal th creation, as distinct from wealth distribution, can come to the fore. Obviously, capitalism is a wealth-creative enterprise that provides wise governments the opportunity for redistribution while developing the concept of a polity. As Novak (1982) maintains, there is a moral culture of capitalism, in which the fact of limited government necessitates individual responsibility, social trust and community, and civility -- ideas that are much needed in Africa. In the African context, which contains so much fragmentation of society and so little sense of community (at least among the clans), the use of government for one's own or group ends is inevitable, as are its concomitants, social disillusionment and denial of political rights. Hayek $(1973,13)$ makes this point in his discussion of government and social justice: 
We have also charged them [govemment] with tasks which they can perform only if they are not thus limited but are free to use coercion in the discriminatory manner that is required to assure benefits to particular people or groups. This they are constantly asked to do in the name of social justice, a conception which has largely taken the place of the justice of individual action. It requires that not the individuals but society be just in determining the share of individuals in the social product; and in order to realize any particular distribution of social product regarded as just it is necessary that government directs individuals in what they must do.

\section{Whither Africa: Back to the Future}

Assume for the moment that African desire to move to increased democracy and market-sensitive economies is not simply the product of economic collapse and of pressure from developed countries and lending organizations such as the World Bank, but rather reflects an awareness of the relative success of reform versus non-reform regimes. Factoring out those countries which suffered significant external shocks (both good and bad) between 1985 and 1987, the growth figures decisively favor the reform regimes, by an average rate of 3.8 percent a year to 1.5 percent (The Economist 23 September 1989,43 ). Then the question becomes, what policies or directions should Africa choose to maximize the interrelated conditions of democracy and economic liberalism? Although this wave of reform effectively celebrates the triumph of micro over macro-economics, by making market allocations central to development efforts and by focusing attention on indigenous obstacles to efficient market economies, there remains a crucial international dimension to continental well-being.

One issue facing Africa as global economic relationships turn increasingly to regional arrangements such as the EEC (including perhaps Eastern Europe), a North American free trade zone, and the possibility of a Japanese-dominated Asian equivalent, is the advisability of reviving N'Krumah's (1965) vision of a unified Africa. Certainly, the benefits of integration can be seen in Europe, where extraregional exports have increased over 85 percent since the Community's inception and the 1992 unification of national markets will (by itself) increase EEC GDP by 4.5 to 6.5 percent, create as many as two million new jobs, and reduce consumer prices 6 percent (Magstadt 1991, 135-136), in addition to saving $\$ 20-30$ billion through the abolition of border controls and administrative formalities (de la Serre 1990,348). Even given the benefits of greater levels of economic cooperation and intercontinental trade, especially in a world that may divide into competing trading blocs, it is essential that Africa refrain from seeking to establish the political kingdom of N'Krumah's vision. Rather, if it is to be competitive as soon as possible, Africa should build more modestly on its growing recognition of the centrality of markets to economic health by promoting intra-African trade. Then, to the extent that Africans see their fates tied to their continent, see that they have 
interests in common, and thus permit responsibility for the assignment of wealth to pass from government to less political, continent-wide market forces, it is more likely that political stability and economic growth will result.

Another aspect of the international dimension is the role of donor states, agencies, and multinational corporations. Africa needs help from abroad if it is ever to meet the increasing demands placed on poor economies and fragile political systems. The data presented above support Hyden's (1983, 204-205, 210) conclusion that although gains are limited, African states that are strongly associated with the world economy are at a developmental advantage compared to those that remain peripheral. Donors, as well as Africans, also must be committed to the process of reform and willing to absorb some of the costs associated with such changes, given that aid programs often have contributed to African problems (Hyden 1983; Whitaker 1988). Beyond additional aid, governmental provision of incentives for investment in Africa, debt rescheduling, and protection against external calamities such as drought and oil shocks, donors should be willing to give Africa the fundamental break that Japan and the young dragons of East Asia enjoyed. Nye (1990) shows how the United States allowed Japan and other states considered crucial to its strategic security interests to engage in business practices that discriminated against American enterprises, pumped billions in aid and private investment into the world economy, and maintained a high value for the dollar that favored East Asia's export-oriented development. Such advantages helped East Asia to pursue a highly competitive and successful export-based approach to development. To the extent that African reforms are real, donors should provide some such preferential access, with sufficient hedges and cut-off dates to insure continuing reform, in order to allow reforming states to develop mainly through their own efforts and not simply through the directed and controlled aid programs of the wealthy nations.

At the same time, the importance of the nation-state and its instrument -government -- are not going to fade away, especially in Africa. Government will remain a central actor in the determination of the character and health of the state. As Richard Sklar (1992) argues, the state will have to be "actively interventionist" in Africa to enhance economic growth and to promote "collective responsibility" for the welfare of all citizens. The question is not, therefore, whether the state will be intimately involved in development efforts, but rather, in what direction will its decisions propel development? Within the scheme of a market-driven economy there seem to be three possible routes states might take to improve the lot of their citizens. Two involve different approaches to the corporatist model (where there is an intimate relationship between the major productive elements of a society, with government playing an active role in coordinating these elements for the national interest), while the third is predicated on more of a pure, market economy. Whatever approach is employed, the hope is that Africans can create developed/ democratic or choice surplus rather than underdeveloped/authoritarian or choice deficient situations and societies. It is, after all, within the provision of individual 
and therefore aggregate opportunities or choice that is found the fundamental definition of progress and the real differences in condition of rich and poor states. Africa, if it is to surmount its history, must identify and select policies that promote political choice, i.e., democracy, and economic choice, i.e., the free market, in order to create values requisite to national development. Government has a role to emphasize and stimulate the cultural and national elements supportive of choice, while seeking, through education and various forms of incentives/disincentives, to vitiate those conditions that restrict individual and national opportunities.

\section{Competitive Corporatism}

Comparison of the South Korean, Taiwanese, European fascist, and Japanese experiences seems to offer some hope for those regimes which believe that economic development is possible without democracy, although the desirability of such is questionable. This approach seems to be characterized by the presence of ethnically homogeneous and/or exclusivist societies, with strong we-group psychological dynamics in which outsiders are viewed with suspicion and as enemies who must be defeated. Van Wolferen (1990) refers often to the tendency of the Japanese to see the world as a struggle, in which they are being persecuted for being "Japanese" and the rest of the world begrudges them the fruit of their labors. He refers to higaisha ishiki or "victim consciousness" to describe how Japanese react to international criticism. Such a society will subordinate individual to group needs, goals, and ambitions, as defined by the ruling "corporate" elite. Given strong social discipline and indoctrination, demands for self sacrifice, high levels of nationalism and ethnocentrism, strong emphases on conformity and obedience to authority, such states can produce economic miracles. Essentially, these states perceive themselves as individual organisms which are in competition with other, often hostile or jealous individual organisms for control of various resources. Thus, real democracy and individual rights pale in significance compared to the drive to maximize organismal advantage. To the extent that competitive corporatist states are considered models for Africa, one might ponder an American diplomat's summary of the Japanese approach: "First, we rig politics so that one party is always in power and the big-city votes basically don't count. Then we double the cost of everything but hold incomes the same. Then we close the borders and start celebrating racial purity. Then we reduce the number of jobs for women by 70 or 80 percent. Then we set up a school system that teaches people not to ask questions" (Nye 1990, 226).

\section{Welfare Corporatism}

Strongly identified with Sweden, Norway, Austria and Switzerland, this approach is considerably different in its effect on individuals and its prognosis for democracy. Such a system is a creature of advanced capitalism (Steiner 1986, 
224), exhibits a sense of national community and shared identity around accepted values, has a perception that the state should maximize individual rights and promote the achievement of individual potential, has a strong moralistic political culture, possesses a large number of highly trained government professionals who deal with problems in a pragmatic, engineering-style decision process, and is more concerned with wealth distribution than wealth creation. Democracy in these states has acted to ameliorate the inequality of condition and result so associated with capitalism, echoing Almond's $(1991,473)$ view that a pragmatic compromise that provides distributive justice "without losing the allocative efficiency and dynamism for private enterprise" can effect the survival and "even enhancement of both of these sets of institutions." Such a rationalized system, where the group serves the individual, can work as long as there is sufficient wealth being produced to share. Yet both Sweden and Norway in recent years have had to scale back the level of government intervention and reduce the burdens on individuals, in order to regain lost international competitiveness.

The value of the above approach for Africa is limited by the pre-capitalist level of African economic progress, though it may represent what many Africans hope will eventuate out of the development process. The existence of highly fractionalized societies, strong ethnic rivalries, corruption, political instability, and the lingering view that the individual should serve the community will militate against welfare corporatism becoming anything more than a dream for years to come.

\section{Government as Facilitator}

This approach is built on the idea that government needs to get out of economic life as much as possible, allowing the market to determine the allocation of goods and services. This is not to say government does not have a role, but rather, as Hayek's $(1948,13)$ citation of Edmund Burke indicates, there is a need for "well constructed institutions" and "rules and principles of contending interests and compromised advantages" so that conflicting interests can be reconciled without allowing one group's views always to prevail over others. To the extent that it is possible for African governments to achieve Adam Smith's simple tasks of defending the people from violence and invasion, protecting individuals from the tyranny or oppression of other members of the society, and providing "certain public works and certain public institutions, which can never be for the interest of any individual, or small number of individuals, to erect and maintain" (The Economist 14 July 1990, 11), it will be possible to achieve greater political stability, economic growth, and prospects for democracy.

Though the last of Smith's tasks seems to require state intervention to meet ever widening circles of need, states would be well advised not to travel very far down this road. Pragmatic public policy should be sensitive not only to the need for some level of state intervention in society, but also (to the extent that ideas do 
matter in the lives of states) to the philosophical and moral consequences of advancing state claims and interests. The statist temptation to plan, regulate, and control has led to economic growth in some cases, but at a real cost to democracy and, eventually, economic efficiency. Rather, African states should employ the resources saved from reducing government expenditures (plus appropriate shares of new revenues) to advance their human and physical infrastructural elements, such as education, health care, communications, good water, and power, which are requisite to future growth. Without proper government investment, Africa will not progress, but such efforts should be aimed at educating, liberating, and empowering the individual in the political as well as economic aspects of life. To the extent that government stimulates individual interdependence, it is possible that Hayek's view of economics as catallaxy, or going beyond mere barter or exchange "to admit into the community and to turn enemy into friend" (Nishiyama and Leube 1984, 367), can transform the African condition.

Africa, as a whole, has thirty years of failure to use as a model of what not to do. Admittedly, the task of building Africa will be neither quick nor revolutionary, even if the market-based model is followed. Certainly, China's recent experience with reform is a sobering example: despite (1) doubling rural incomes in six years, (2) quadrupling the growth rate of farmers' output from 2 percent (1958-78) to 8 percent (1979-84), (3) a trade surplus in 1990 of some $\$ 9$ billion, and (4) increasing its non-state firms' share of total industrial output to approximately fifty percent (The Economist 1 June 1991, 15-18), the totalitarian/ authoritarian temptation obviously remains strong. Although the world must play a part by providing fair access to the resources and markets needed to reduce Africa's debilitating dependency on foreign donors and their sometimes illconceived aid schemes, it remains primarily the responsibility of Africans to begin the process of reform necessary to bring market forces into play and to mitigate the problems of tribalism, corruption, and political instability that plague African regimes. Hopefully, African states can avoid China's example of state terror and repression of the very people and forces that made its recent success possible. In any case, the quicker the people of Africa make a real choice for greater democracy and economic liberalism, the sooner the long and difficult road ahead can be traversed.

\section{NOTES}

${ }^{1}$ Hong Kong is not included in Table 1 because of its peculiar relationship with Great Britain.

${ }^{2}$ Market indicates more entrepreneurial/private enterprises. Participation indicates foreign investment welcomed with sensitivity to markets, though with government participation in foreign firms. Mixed indicates some government enterprise, with some foreign investment and some private enterprise. State control indicates dominance of 
public sector enterprises, limited and controlled foreign investment. Planned indicates controlled socialist economy with nationalization of foreign enterprises.

\section{REFERENCES}

Ake, Claude. 1990. The Case for Democracy. In African Governance in the 1990s: Objectives, Resources, and Constraints. Working Papers from the Second Annual Seminar of the African Governance Program, The Carter Center of Emory University, Atlanta, GA.

Almond, Gabriel A. 1991. Capitalism and Democracy. PS: Political Science \& Politics 24: 467-473.

Alozie, Nicholas O. 1991. Privatization, Evangelism and Public Management in SubSaharan Africa: The Case of Nigeria. Paper presented at the annual meeting of the International Studies Association-Southwest, San Antonio, TX.

Bates, Robert H. 1990. Socio-Economic Bases of Democratization in Africa: Some Reflections. In African Governance in the 1990s: Objectives, Resources, and Constraints. Working Papers from the Second Annual Seminar of the African Governance Program, The Carter Center of Emory University, Atlanta, GA. 1991. The Economics of Transition to Democracy. PS: Political Science and Politics 24: 24-27.

Bohannan, Paul and Philip Curtin. 1988. Africa and Africans, 3rd ed. Prospect Heights, IL: Waveland Press.

Chazan, Naomi, Robert Mortimer, John Ravenhill, \& Donald Rothchild. 1988. Politics and Society in Contemporary Africa. Boulder, CO: Lynne Rienner Publishers.

Chege, Michael. 1988. The African Economic Crisis and the Fate of Democracy in SubSaharan Africa. In Walter O. Oyugi, E.S. Atieno Odhiambo, Michael Chege, and Afria K. Gitonga, eds., Democratic Theory and Practice in Africa. Portsmouth: Heinemann Publishers.

de la Serre, Francoise. 1990. The European Economic Community: Economic and Political Union. In Roy C. Macridis, ed., Modern Political Systems: Europe. Englewood Cliffs, NJ: Prentice Hall.

Economist, The. 20 June 1987. Survey: East Africa. 303: 3-18.

4 March 1989. Africa's Hope. 310: 13-14.

23 September 1989. Survey: Poor Man's Burden. 312: 3-58.

23 June 1990. Goodbye to the Nation State. 315: 11-12.

14 July 1990. Taiwan and Korea. 316: 19-12.

14 July 1990. The Modern Adam Smith. 316: 11-12.

22 December 1990. The State of the Nation State. 317: 43-46.

22 December 1990. The Year the Votes Poured In. 317: 75-76.

1 June 1991. They Couldn't Keep It Down. 319: 15-18.

28 February 1992. Democracy in Africa. 322: 17-20.

Enloe, Cynthia H. 1973. Ethnic Conflict and Political Development. Boston: Little, Brown.

Fatton, Robert Jr. 1990. Liberal Democracy in Africa. Political Science Quarterly 105: 455-473.

Friedman, Milton. 1962. Capitalism and Freedom. Chicago: University of Chicago Press. 
Friedman, Milton and Rose Friedman. 1980. Free to Choose. New York: Harcourt Brace Jovanovich.

Gamer, Robert E. 1976. The Developing Nations: A Comparative Perspective. Boston: Allyn and Bacon.

Geertz, Clifford. 1971. The Integrative Revolution: Primordial Sentiments and Civil Politics in New States. In Jason L. Finkle and Richard W. Gable, eds., Political Development and Social Change, 2nd ed. New York: John Wiley \& Sons.

Harrison, Paul. 1981. Inside the Third World, 2nd ed. New York: Penguin Books.

Hayek, Friedrich A. 1944. The Road to Serfdom. Chicago: University of Chicago Press. 1948. Individualism and Economic Order. Chicago: University of Chicago Press.

. 1973. Economic Freedom and Representative Government. Tonbridge, England: Institute for Economic Affairs.

Heilbroner, Robert L. 1961. The Worldly Philosophers, 2nd ed. New York: Simon and Schuster.

Hodder-Williams, Richard. 1984. An Introduction to the Politics of Tropical Africa. London: George Allen \& Unwin.

Hyden, Goran. 1983. No Shortcuts to Progress: African Development Management in Perspective. Berkeley: University of California Press.

Ilchman, Warren F. and Norman Thomas Uphoff. 1971. The Political Economy of Change. Berkeley: University of California Press.

Lofchie, Michael F. 1971. Political Constraints on African Development. In Michael F. Lofchie, ed., The State of the Nations: Constraints on Development in Independent Africa. Berkeley: University of California Press.

Magstadt, Thomas M. 1991. Nations and Governments: Comparative Politics in Regional Perspective. New York: St. Martin's Press.

Mbembe, Achille. 1990. Democratization and Social Movements in Africa. Africa Demos: A Bulletin of the African Governance Program, The Carter Center of Emory University 1: 4.

Morrison, Donald G. 1989. Understanding Black Africa: Data and Analysis of Social Change and Nation Building. New York: Irvington Publishers.

Nau, Henry R. 1990. The Myth of America's Decline: Leading the World Economy into the 1990s. New York: Oxford University Press.

Nishiyama, Chiaki and Kurt R. Leube. 1984. The Essence of Hayek. Stanford,CA: Hoover Institution Press.

Nkrumah, Kwame. 1965. Neo-Colonialism: The Last Stage of Imperialism. New York: International Publishers.

Novak, Michael. 1982. The Spirit of Democratic Capitalism. New York: Simon and Schuster.

Nye, Joseph Jr. 1990. Bound to Lead. The Changing Nature of American Power. New York: Basic Books.

Nyong'o, P. Anyang. 1990. Democracy and Political Instability: A Rejoinder to the Comments by Dr. Thandika Mkandawire. In African Governance in the 1990s: Objectives, Resources, and Constraints. Working Papers from the Second Annual Seminar of the African Governance Program, The Carter Center of Emory University, Atlanta, Georgia.

Nzouankeu, Jacques-M. 1991. The African Attitude to Democracy. International Social Science Journal 43: 373-385. 
Palmer, Monte. 1989. Dilemmas of Political Development: An Introduction to the Politics of the Developing Areas, 4th ed. Itasca, IL: Peacock.

Peil, Margaret. 1977. Consensus and Conflict in African Societies. London: Longman. Pye, Lucien W. 1966. Aspects of Political Development. Boston: Little, Brown.

Sklar, Richard L. 1983. Democracy in Africa. African Studies Review 26: 11-24. 1992. Beyond Capitalism and Socialism in Africa. In Charles K. Wilber and Kenneth P. Jameson, eds., The Political Economy of Development and Underdevelopment. New York: McGraw Hill.

Smiley, Xan. 1982. Misunderstanding Africa. The Atlantic Monthly 250 (September): 7079.

Steiner, Jurg. 1986. European Democracies. New York: Longman.

Tordoff, William. 1984. Governments and Politics in Africa. Bloomington: Indiana University Press.

Tubman, Winston B. 1986. Pluralism, Constitutionalism, and Law in Africa: A Liberian View. In Dov Ronen, ed., Democracy and Pluralism in Africa. Boulder, CO: Lynne Rienner Publishers.

Turnbull, Colin M. 1972. The Mountain People. New York: Simon and Schuster.

United States Arms Control and Disarmament Agency. 1989. World Military Expenditures and Arms Transfers, 1989. Washington, DC: Department of State. . 1980. World Military Expenditures and Arms Transfers, 1968-1978. Washington, DC: Department of State. 1983. World Military Expenditures and Arms Transfers, 1971-1980.W ashington, DC: Department of State.

Usher, Dan. 1981. The Economic Prerequisite to Democracy. New York: Columbia University Press.

Vanhanen, Tatu. 1990. The Process of Democratization: A Comparative Study of 147 States, 1980-1988. New York: Crane Russak.

Van Wolferen, Karel. 1990. The Japan Problem Revisited. Foreign Affairs 69: 42-55.

Vengroff, Richard. 1990. Rural Development, Policy Reform, and the Assessment of Management Training Needs of Africa: A Comparative Perspective. Public Administration Quarterly 14: 353-376.

Von der Mehden, Fred R. 1964. Politics of Developing Nations. Englewood Cliffs, NJ: Prentice-Hall.

Wallerstein, Immanuel. 1971. The Range of Choice: Constraints on the Policies of Governments of Contemporary African Independent States. In Michael Lofchie, ed., The State of the Nations: Constraints Upon Development in Independent Africa. Berkeley: University of California Press.

. 1974. Dependence in an Interdependent World. African Studies Review 17: 126.

Weiner, Myron. 1971. Political Integration and Political Development. In Jason L. Finkle and Richard W. Gable, eds., Political Development and Social Change, 2nd ed. New York: John Wiley \& Sons.

Whitaker, Jennifer S. 1988. How Can Africa Survive. New York: Council on Foreign Relations Press.

Wilson, James Q. 1990. Juridical Democracy versus American Democracy. PS : Political Science and Politics 23: 570-572.

Wiseman, John A. 1990. Democracy in Black Africa: Survival and Renewal. New York: Paragon House. 
Wunsch, James S. and Dele Olowu. 1990. The Failure of the Centralized State: Institutions and Self-Governance in Africa. Boulder, CO: Westview Press.

Zacher, Mark W. and R. Stephen Milne. 1974. Introduction. In Mark W. Zacher and R. Stephen Milne, eds., Conflict and Stability in Southeast Asia. New York: Anchor Press. 